doi http://dx.doi.org/10.18542/rmi.v13i21.9548

\title{
TESTEMUNHO DA EXPERIÊNCIA DA INFÂNCIA NO EXÍLIO E SUA REPRESENTAÇÃO NO CONTO INFANTO-JUVENIL MENINOS SEM PÁTRIA, DE LUIZ PUNTEL
}

\section{TESTIMONY OF THE EXPERIENCE OF CHILDHOOD IN EXILE AND ITS REPRESENTATION IN THE CHILDREN'S TALE BOYS WITHOUT HOMELAND, BY LUIZ PUNTEL}

Ladyana dos Santos LOBATO ${ }^{1}$ Universidade Federal do Pará

Tânia Maria Pereira SARMENTO-PANTOJA ${ }^{2}$

Universidade Federal do Pará

\begin{abstract}
Resumo: Analisamos o testemunho de filhos de militantes politicos da Ditadura Militar de 1964, que reporta à experiência da infância no exílio e a forma com que essa experiência fora representada na produção literária. Para isso, selecionamos dois objetos de estudos: 1) A narrativa testemunhal "Por que você é tão tristinha?", de Marta Nehring, publicada em 2014; e 2) A narrativa ficcional Meninos sem Pátria, de Luiz Puntel, publicada em 1988. Utilizamos como referencial teórico os estudos sobre testemunho (SELIGMANN-SILVA, 2008, 2001); memória (SARLO, 2007; BASILE, 2019); literatura de testemunho (MARCO, 2004; SELIGMANN-SILVA, 2003; LUQUE, 2003); exilio (SAID, 2003; VIÑAR; VINÃR, 1992; ROLLEMBERG, 2007; BIROL, 2017; MONTAÑÉS, 2006); e utopia (SZACHI, 1972). Verificamos que as narrativas selecionadas apresentam um conjunto de características inerentes à experiência de exílio das crianças, dentre elas, a compreensão do exílio como um lugar utópico, espaço de liberdade, sobrevivência e resistência ao autoritarismo em estados de exceção.
\end{abstract}

Palavras-chaves: Exílio. Testemunho. Infância. Utopia. Sobrevivência.

\begin{abstract}
We analyzed the testimony of the children of political militants of the Military Dictatorship of 1964, which reports on the experience of childhood in exile and the form with which that experience was represented in literary production. For this, we selected two objects of study: 1) The testimonial narrative "Why are you so sad?" by Marta Nehring, published in 2014 and; 2) The fictional narrative Homelass boys, by Luiz Puntel, published in 1988. We use testimony studies as a theoretical framework (SELIGMANNSILVA, 2008, 2001); memory (SARLO, 2007; BASILE, 2019); testimony literature (MARCO, 2004; SELIGMANN-SILVA, 2003; LUQUE, 2003); exile (SAID, 2003; VIÑAR; VINÃR, 1992; ROLLEMBERG, 2007; BIROL, 2017; MONTANÉS, 2006); and utopia (SZACHI, 1972). We found that the selected narratives present a set of characteristics inherent to the children's exile experience, among them, the understanding of exile as a utopian place, a space of freedom, survival and resistance to authoritarianism in states of exception.
\end{abstract}

Keywords: Exile. Testimony. Childhood. Utopia. Survival.

\footnotetext{
${ }^{1}$ Universidade Federal do Pará (UFPA).E-mail: ladyanasl@ufpa.br.

${ }^{2}$ Orientadora. Universidade Federal do Pará (UFPA).E-mail: t.sarmentopantoja@gmail.com.
} 


\section{Introdução}

O exílio faz parte do passado recente da História de países da América Latina, como Peru, Chile, Bolívia, Argentina, Brasil, Uruguai e Paraguai, os quais tiveram em comum a experiência de ditaduras militares. No Brasil, o regime ditatorial teve início no dia $1^{\circ}$ de abril de 1964, com o golpe no governo do presidente eleito João Goulart, e perdurou por 21 (anos), com a alternância de militares no posto de chefe de Estado. O regime perpassou um intenso período de repressão, censura, perseguição, violência, desaparecimentos e mortes. Nesse contexto, muitas pessoas foram obrigadas a exilar-se em outros países da América Latina ou da Europa. Entre os principais motivos para isso, podemos citar a ameaça de prisão, tortura e morte, a dificuldade de se manter na clandestinidade, a sobrevivência, a proteção da família (esposo, esposa, filhos), o banimento e a recusa a viver em um país sob o jugo de uma ditadura. Dessa forma, o exílio pode ser compreendido como uma possibilidade de resistência à opressão imposta pelo regime ditatorial, o que torna a experiência das pessoas exiladas tão importante quanto a experiência daqueles que continuaram no país frente à luta armada ou daqueles que conseguiram sobreviver na clandestinidade.

Neste estudo, verificamos a necessidade de considerar como exilado não somente aquele que foi banido, forçado ou que se recusou a viver em um país em ditadura, pois “exilados foram também homens, mulheres, adolescentes e crianças que partiram não devido às suas atividades, mas acompanhando seus maridos, esposas, pais e mães. Foram todos exilados” (ROLLEMBERG, 2007, p. 2). Neste limiar, destacamos as crianças, adolescentes e jovens, filhos de ex-desterrados políticos, os quais se tornaram exilados porque acompanharam seus pais ou responsáveis na viagem para o exílio e, neste contexto, também foram impedidos de voltar para casa, conforme postula Said (2003). No caso dos filhos, o deslocamento não é uma questão de escolha, mas uma prática involuntária e precoce; às vezes, a única possibilidade de sobrevivência ao regime de estado de exceção.

Assim, para analisar a experiência da infância no exílio, precisamos recorrer às produções construídas a partir do testemunho dos filhos de perseguidos, desaparecidos e mortos políticos da Ditadura Militar de 1964. Neste contexto, analisamos a narrativa testemunhal intitulada "Por que você é tão tristinha?", de Marta Nehring, filha de Norberto Nehring, assassinado pelo Estado autoritário em 1970. Marta Nehring nasceu em São Paulo, em janeiro de 1964, estudou literatura e cinema e, atualmente, trabalha como roteirista de cinema e televisão. A sobrevivente testemunhou aos 49 anos de idade em um ciclo de audiências realizado pela Comissão da Verdade do Estado de São Paulo "Rubens Paiva", em 2013. Em 2014, o testemunho fora publicado na obra intitulada Infância roubada. A obra reuniu o depoimento de 40 (quarenta) filhos de presos políticos, perseguidos e 
desaparecidos da ditadura. Nessa obra, é possível encontrar ainda 9 (nove) testemunhos que tratam da experiência do exílio.

Neste estudo, propomos uma discussão que envolve a forma como a literatura representou esse tipo de experiência no campo ficcional. Por isso, analisamos a narrativa infanto-juvenil intitulada Meninos sem Pátria, do escritor Luiz Puntel, publicada em 1988, pela Editora Vaga-lume. Na obra, o narrador-testemunha, Marcos, na condição de adulto, reporta à experiência do exílio vivenciada na época da Ditadura Militar no Brasil, ocasião em que tinha apenas 10 anos de idade. A narrativa é inspirada na experiência do exílio vivenciada por José Maria Rabêlo, sua esposa e 7 (sete) filhos. Meninos sem Pátria é o livro mais vendido da Editora Vaga-lume. Recentemente, fora acusado de “apologia ao comunismo" e retirado da lista de leitura dos alunos do $6^{\circ}$ ano de um colégio católico, no Rio de Janeiro.

Este artigo dialoga com os estudos sobre testemunho, realizados por teóricos da literatura como Márcio Seligmann-Silva (2001, 2008); os estudos de memória realizados por Beatriz Sarlo (2007) e Teresa Basile (2019); o conceito de literatura de testemunho, conforme empregado por Valéria de Marco (2004), Cecília de Luque (2003) e Selligmann-Silva (2003); os estudos teóricos sobre o exílio, realizados por críticos como Edward Said (2003), Maren Viñar e Marcelo Vinãr (1992) e Denise Rollemberg (2007). Citamos ainda o conceito de utopia, conforme proposto por Jerzy Szachi (1972).

Nesta pesquisa, verificamos que a narrativa testemunhal "Por que você é tão tristinha?", de Marta Nehring e a narrativa ficcional Meninos sem Pátria, de Luiz Puntel, reelaboram a experiência do exílio por meio da memória da segunda geração atingida pelo regime de estado de exceção. Neste processo, é possível verificar a memória transmitida dos pais aos filhos e o trabalho de rememoração da experiência vivenciada pelas próprias crianças na época da matéria histórica. Neste limiar, será possível perceber que as narrativas apresentam um conjunto de características inerentes à experiência de exílio das crianças. Será possível notar também uma compreensão do exílio como um espaço de liberdade, condição produtiva para a reflexão sobre a sobrevivência e a resistência ao autoritarismo em estados de exceção.

\section{Reflexões sobre o testemunho e a memória da experiência do exílio de Marta Nehring}

O conceito de testemunho encontrou espaço teórico-crítico na América Latina, sobretudo, a partir dos anos de 1960, no contexto histórico das ditaduras civil-militares que afligiram os países do Cone Sul. A partir desse período é possível encontrar uma vasta produção testemunhal, constituída a 
partir dos relatos dos sobreviventes, coletados em tribunais de justiças, pesquisas acadêmicas, publicações de livros, entrevistas, produções literárias, cinematográficas, entre outras fontes, especialmente em países como Argentina, Chile e Uruguai. De acordo com Sarlo (2007), o testemunho

é composto daquilo que um sujeito permite ou pode lembrar, daquilo que ele esquece, cala intencionalmente, modifica, inventa, transfere de um tom ou gênero a outro, daquilo que seus instrumentos culturais lhe permitem captar do passado, que suas ideias atuais lhe indicam que deve ser enfatizado em função de uma ação política ou moral no presente, daquilo que ele utiliza como dispositivo retórico para argumentar, atacar ou defender-se, daquilo que conhece por experiência e pelos meios de comunicação, e que se confunde, depois de um tempo, com sua experiência (SARLO, 2007, p. 59).

De acordo com Seligmann-Silva (2007, p. 73), "o testemunho é uma modalidade da memória”. Para Seligmann-Silva (2001), a pessoa traumatizada não encontra linguagem adequada para traduzir a experiência do choque e, desta forma, não é possível recuperar a experiência. Na narrativa testemunhal "Por que você é tão tristinha?", Marta Nehring admite que "havia aquele clima opressivo de ditadura, que é tão difícil de explicar para quem não viveu" (NEHRING, 2014, p. 45). O fracasso da testemunha, portanto, em narrar experiências traumáticas dos regimes de estados de exceção ocorre devido à ausência de recursos linguísticos "adequados" para essa tarefa que precisa adentrar territórios obscuros da memória, marcados pela violência, pela impotência, pela necessidade de lembrar, mas também de esquecer. Nessa perspectiva, Marta Nehring afirma:

(...) até hoje tenho pesadelos horríveis. Com frequência acordo - anteontem mesmo aconteceu - com a certeza de ter alguém no quarto. Depois fiquei sabendo que, numa das vezes em que a polícia esteve em casa, revirando tudo, entraram no quarto onde eu dormia, acho que devia ter uns 4 anos (NEHRING, 2014, p. 39, grifo nosso).

No caso de Marta, percebemos que a memória não faz o registro, isto é, não traz a símbolo nenhum fragmento do momento em que a polícia invadiu sua casa e entrou no seu quarto. No entanto, a testemunha afirma ter pesadelos constantes, que podem estar associados a esta experiência. Apesar da ausência de recordação, verificamos que a testemunha reconstitui o evento utilizando, para isso, as informações que lhe foram transmitidas em momento posterior, pois, na época do fato testemunhado, Marta deveria ter em torno de 4 (quatro) anos de idade. Verificamos, portanto, que estamos diante do testemunho das memórias do que veio a ser conhecido como "a segunda geração" ou "a geração depois" das vítimas diretas da matéria histórica. Basile (2019) considera conveniente 
o conceito de "segunda geração", tendo em vista as diferenças existentes com relação à primeira geração. "Além disso, as políticas de terror do Estado sobre as duas gerações eram muito diferentes (...) O ponto de confluência é, sem dúvida, o caráter de vítima que atinge, embora de maneira diferente, as duas gerações" (BASILE, 2019, p. 32, tradução nossa).

Assim, uma questão central nesta abordagem é o entendimento de que alguns eventos testemunhados pelos filhos não foram diretamente experienciados por esta geração, dessa forma, o ato de "'lembrar' torna possível o deslocamento entre lembrar o vivido e 'lembrar' narrações ou imagens alheias e mais remotas no tempo" (SARLO, 2007, p. 90). Para Basile (2019), a experiência da infância tem sua particularidade porque se relaciona com duas memórias. "Às vezes, porém, coincidem e se misturam, se cruzam, são difíceis de demarcar” (BASILE, 2019, p. 33, tradução nossa). De acordo com a pesquisadora, a natureza da memória da segunda geração está na tensão existente entre a memória dos pais e a memória dos filhos. Trata-se de uma "memória dupla, dual, crispada entre dois polos que buscam acomodar-se entre si” (BASILE, 2019, p. 15, tradução nossa). Para Sarlo (2007), é evidente que, "se o passado não foi vivido, seu relato só pode vir do conhecido através de mediações; e, mesmo se foi vivido, as mediações fazem parte desse relato" (SARLO, 2007, p. 92); ou seja, é por meio da mediação do discurso de terceiros que os filhos conseguem testemunhar sobre os acontecimentos históricos, tendo em vista que, na época do evento, alguns deles eram muito pequenos, e outros ainda não tinham nascido.

Na narrativa testemunhal "Por que você é tão tristinha?", Marta Nehring afirma que nasceu em janeiro de 1964, ou seja, no mesmo ano em que ocorrera o golpe militar. A testemunha discorre sobre a formação acadêmica e profissional de seus pais, assim como sobre a trajetória política desenvolvida na Ação Libertadora Nacional (ALN). Além disso, o testemunho de Marta trata sobre as ameaças e perseguições que motivaram a fuga da família para o exílio, a viagem, a estada e o retorno da família para o Brasil. Neste estudo, abordamos sobre a estada de Marta Nehring no exílio, com a finalidade de evidenciar algumas características inerentes a esta experiência. Marta partiu com sua mãe para o exílio em Cuba, pois o seu pai já se encontrava exilado nesse país, onde fazia treinamento militar. De acordo com Marta, seu pai fora assassinado quando voltou clandestino ao Brasil. Marta e sua mãe tiveram conhecimento da morte de Norberto Nehring somente meses depois, quando as duas já estavam em exílio na França. O corpo do pai de Marta fora reconhecido por meio da arcada dentária, não permitiram autópsia.

De acordo com a sobrevivente: “Aí começou o exílio e... Sei lá, eu tinha que me adaptar, ponto" (NEHRING, 2014, p. 44). Verificamos que somente após a morte do pai e a viagem para o segundo país de exílio, a França, é que a testemunha reconhece a condição de ser exilada. Isto ocorre 
porque, de acordo com Rollemberg (2007), nos primeiros anos, o exílio fora considerado como algo temporário, uma preparação para "retornar ao Brasil em condições mais apropriadas e reassumir a luta contra a ditadura ou contra o capitalismo" (ROLLEMBERG, 2007, p.4). Nesse contexto, os exilados sequer consideravam que os tempos eram de exílio; dessa forma, verificamos a possibilidade de que essa noção fora transmitida dos pais aos filhos.

Com a posse de Salvador Allende no Chile, Marta, sua mãe e o marido dela partiram para esse país por questões de segurança, mas também pela proximidade com o Brasil. Sobre o exílio no Chile, Marta discorre sobre o sentimento de nostalgia, especialmente quando rememora as ligações internacionais: “(...) ligar para o Brasil era ao mesmo tempo uma glória e um tormento: só dava pra dizer 'Vovó, tô com saudade' e tinha que desligar. Era um negócio de louco" (NEHRING, 2014, p. 44). De acordo com Viñar e Viñar (1992), a nostalgia trata-se da evocação, ao mesmo tempo agradável e dolorosa, a um imaginário criado sobre a terra perdida: ela é a melhor e está lá, ao longe. No entanto, de acordo com Boym (2017), a nostalgia parece ser a saudade de um lugar, mas, na verdade, é um anseio por um tempo diferente e melhor. É nesse contexto que percebemos que, para Marta Nehring, a nostalgia representou a saudade de um tempo passado, atrelado principalmente ao convívio familiar e à memória de vida do pai: "Acho que o mais excruciante, durante o exílio, foi a saudade da família, que ficara no Brasil, e do meu pai. Foi horrível” (NEHRING, 2014, p. 44).

Após o golpe de 1973 no Chile, Marta e sua família fugiram de lá, e voltaram para a França. Sobre esta segunda experiência de exílio na França, Marta rememora o processo de adaptação: "Era adaptação o tempo todo: língua, escola, colega, vizinhança” (NEHRING, 2014, p. 44). De acordo com Birol (2017), faz parte do processo de adaptação do estrangeiro o aprendizado de esquemas, papéis sociais e significados específicos daquela sociedade ou cultura. De certa forma, é "como regressar ao processo mais primário de socialização do ser humano e reaprender coisas que na sociedade de origem lhe pareciam simples" (BIROL, 2017, p. 45). No que concerne à experiência das crianças, no entanto, Viñar e Viñar (1992) afirmam que estas são as primeiras a entrarem em contato com o ambiente do país de exílio, por meio do acesso à escola e da facilidade em aprenderem a língua. Essas questões corroboram o êxito da adaptação das crianças quando comparado à adaptação dos adultos.

Sobre esta segunda experiência de exílio na França, Marta discorre também sobre a condição de estrangeira: "E mesmo sendo bem quista, continuava sendo estrangeira. Cheguei a brigar na escola com uma menina xenófoba. Em suma, o exílio não era só glória, também havia aqueles que não iam com a sua cara porque você era brasileira e, pior ainda, filha de comunista." (NEHRING, 2004, p. 44). O estrangeiro é "aquele que não faz parte do grupo, aquele que não 'é dele', o outro." 
(KRISTEVA, 1994, p. 100). Sendo assim, o termo "estrangeiro" designa, nessa abordagem, aquele que não pertence à determinada nação, ou seja, não possui a nacionalidade do país em que vive e, portanto, é considerado como o "diferente", em alguns casos, como o "estranho" ou o "intruso". Kristeva (1994, p. 13) enfatiza que o estrangeiro "é aquele que perdeu a mãe". A "mãe" é uma metáfora para o Estado-nação, portanto, o estrangeiro é aquele que perdeu o vínculo com o seu país de origem, e para o país de recepção, "ele é uma boca a mais, uma palavra incompreensível, um comportamento incomum" (KRISTEVA, 1994, p. 13), aspectos que o ferem violentamente, especialmente nos primeiros instantes.

De forma geral, no testemunho da experiência de exílio de Marta Nehring, identificamos a presença de um discurso utópico, pois o exílio é compreendido como um espaço de liberdade, no qual é possível viver livre das condições de aprisionamento impostas pelas relações sociais e políticas dos países em regime de ditadura. Observamos, por exemplo, que Marta testemunha sobre a experiência de felicidade vivenciada no Chile, antes do golpe de 1973: "Mas eu me adaptei e afinal fui feliz, aprendi várias línguas, fiz amigos nas escolas que frequentei” (NEHRING, 2014, p. 44, grifo nosso). Sobre a experiência de exílio na França, ela afirma: "Mas eu também fui feliz nesse retorno à Europa. Primeiro, era ótima aluna e querida pelos meus colegas. Ademais, ser exilado político era bem-visto, eu não precisava mentir sobre a minha identidade, podia dizer que meu pai era um guerrilheiro que morreu na luta contra os fascistas" (NEHRING, 2014, p. 44, grifo nosso).

De acordo com Szachi (1972), o termo utopia é utilizado para designar "qualquer visão de uma sociedade melhor sem que se leve em conta a questão da chance que tem de ser realizada". Dessa forma, verificamos que Chile e França representaram, para a testemunha, esse tipo de sociedade. Quando a manifestação da utopia está em determinada região geográfica do mundo, estamos diante de uma utopia de lugar. Para Szachi (1972) a utopia de lugar é:

[...] a convicção de que o país feliz existe, mas está separado de nós por mares e oceanos, desertos e continentes, fronteiras e barreiras. Para chegar lá é preciso abandonar o que para outros, talvez, é a felicidade mesma; há que renunciar a tudo aquilo que herdamos e que nos foi dado. Não se pode ser cidadão dos dois mundos ao mesmo tempo. A conquista do novo mundo é ao mesmo tempo o abandono do velho (SZACHI, 1972, p. 45).

Assim, verificamos que a viagem de Marta ao exílio alcançou um destino utópico, isto é, um local ideal, o desejo utópico de cidade, onde seria possível viver em segurança e liberdade. Esse sentimento não fora sentido pela sobrevivente no Brasil: “[...] ter vivido uma infância assombrada por uma instância arbitrária a ponto de matar meu pai, me expôs a uma tremenda fragilidade e 
potencializou todos os medos" (NEHRING, 2014, p. 47). Sobre o retorno do exílio ao Brasil, a testemunha afirma que não conseguiu ser feliz: "Eu era aquela que estava sempre de cara fechada. E isso me era cobrado: 'Por que você é tão tristinha?'” (NEHRING, 2014, p. 46). A frase que intitula o testemunho de Marta, portanto, é uma referência ao sentimento de tristeza sentido pela sobrevivente, que marcou toda a sua infância e potencializou os seus medos, a insegurança e a angústia, além da sensação de perseguição que a testemunha sente até os dias de hoje.

Ao discorrer sobre o sentimento de nostalgia, o processo de adaptação, a condição de estrangeiro e a visão utópica, verificamos que a testemunha de segunda geração se constitui a partir da memória de outro tempo (vivido ou não). Neste movimento, apesar da (e devido à) mediação de terceiros, a testemunha elabora novos sentidos para o acontecimento. A representação, portanto, requer o trabalho da elaboração do trauma, o qual, de acordo com Basile (2019), pode ocorrer no espaço da psicanálise ou nas possibilidades de construção de uma história por meio da literatura e da arte. É neste contexto que a arte se constitui como o caminho possível para narrar experiências extremas de violência, aquelas que seriam impossíveis de contar senão pelo uso da imaginação.

\section{Reflexões sobre a representação do testemunho e da memória da experiência do exílio no campo ficcional}

Os textos literários que possuem temáticas que abordam as grandes catástrofes ocorridas no século XX, tais como as guerras mundiais, as experiências nos campos de concentração e as ditaduras civil-militares na América Latina, compõem o que podemos chamar de literatura de testemunho. De acordo com Marco (2004), a expressão literatura de testemunho remete sempre a uma relação entre literatura e violência. Para a pesquisadora, é importante reconhecer duas grandes concepções de literatura de testemunho, que, até o momento, não dialogam entre si: "Uma delas desenvolve-se no âmbito dos estudos sobre a literatura latino-americana; outra é dominante no campo da reflexão sobre a Shoah, termo amplamente utilizado para substituir a palavra holocausto" (MARCO, 2004, p.45). De acordo com a pesquisadora, nesta última concepção de literatura de testemunho, é possível reconhecer duas tendências:

Uma, hegemônica, reserva-a à produção dos sobreviventes, recusa-lhe qualquer aproximação à ficção, examina-a a partir de critérios éticos e nega-se a considerá-la à luz da estética. A outra tendência, ao contrário, privilegia em seu exercício crítico as questões de natureza literária, desdobrando-se assim no âmbito da estética; não restringe seu corpus à produção dos sobreviventes (MARCO, 2004, p. 57). 
A primeira tendência fundamenta-se na impossibilidade de vincular testemunho e ficção devido a uma postura ética que exige o relato da verdade. Refere-se exclusivamente às experiências vividas nos campos de concentração nazistas, dentre as quais podemos citar a experiência de Primo Levi, fonte primeira dos estudiosos do testemunho. Na narrativa testemunhal intitulada Os afogados e os sobreviventes, Levi (1990) considera que as "testemunhas integrais" do evento são aquelas que morreram nas câmaras de gás e fornos crematórios, e, por isso, não puderam voltar para narrar. Dessa forma, o testemunho possui uma barreira intransponível, realizável para responder a uma necessidade interior e dar notícia daqueles que não puderam falar. Nesta perspectiva, a experiência é um "imperativo ético e dela deriva um perfil único de autor - o sobrevivente - e uma exigência em relação à obra - a de corresponder à 'verdade dos fatos"” (MARCO, 2004, p. 58).

Neste momento, voltamo-nos, especialmente, para o campo da segunda tendência da literatura de testemunho, aquela que retrata as marcas da convivência com o horror por meio do conteúdo ficcional. De acordo com Marco (2004), esta tendência não restringe a narrativa ao testemunho dos sobreviventes dos campos nazistas, ao contrário, "toma a reflexão sobre eles para apurar a análise da sociedade contemporânea" (MARCO, 2004, p. 58). Nesse sentido, esta tendência não apresenta fronteiras étnicas, geográficas ou linguísticas, pois a representação da violência chega por meio da voz dos mais diversos sujeitos (sobreviventes ou não) de catástrofes históricas, dentre os quais destacamos os atingidos pelas ditaduras latino-americanas.

Marco (2004, p. 57) assegura que, também, no plano literário, “o escritor interroga-se sobre a possibilidade de encontrar a frase justa e a imagem adequada, sobre o poder de expressão da palavra e os impasses de traduzir o vivido, de dizer o indizível". Dessa forma, o que fundamenta essa tendência é a constatação da "insuficiência da linguagem diante de fatos (inenarráveis) como também - e com um sentido muito mais trágico - a percepção do caráter inimaginável dos mesmos e da sua consequente inverosimilhança" (SELIGMANN-SILVA, 2003, p. 46).

Para Seligmann-Silva (2003), a ficção torna-se uma saída para a representação do autoritarismo e da violência. Para isso, o texto literário utiliza vários tipos de ferramentas, entre elas, as "figuras de linguagem, as sobreposições de períodos temporais, a narração em terceira pessoa, a criação de personagens imagináveis, as metáforas" (SELIGMANN-SILVA, 2003, p. 378). Isso ocorre diante da impossibilidade de existência de uma narração verídica daquilo que aconteceu, tal como ocorreu; e da noção de que entre a experiência e a sua expressão existe uma lacuna que a linguagem não consegue decifrar. De acordo com Luque (2003), o conteúdo desse tipo de narrativa é resultado da intervenção de um escritor que criou "uma história que se assemelha a um testemunho ou trabalhou literariamente um relato testemunhal (próprio ou alheio)" (LUQUE, 2003, p. 17, tradução nossa). 
Em Meninos sem pátria, Puntel (2006) realiza o trabalho ficcional de um testemunho alheio, pois a narrativa é uma reelaboração ficcional do testemunho de José Maria Rabêlo e sua esposa Thereza Rabêlo sobre a experiência constante de fuga e exílio que viveram com seus 7 (sete) filhos, durante a ditatura militar do Brasil, Bolívia e Chile. ${ }^{3}$ Após fugirem dos regimes ditatoriais de cada um dos países citados, a família exilou-se na França e retornou ao Brasil, em 1979, por ocasião da anistia política. Na narrativa ficcional, o narrador-testemunha chama-se Marcos, porém, é identificado também por Marcão: "Lá em casa, até hoje, todo mundo me chama assim, de Marcão, por causa do meu jeito desengonçado de quem cresceu demais” (PUNTEL, 2006, p. 13). Na época do evento histórico, o narrador-testemunha tinha 10 (dez) anos de idade. Ele é fillho de Zé Maria e Terezinha (Tererê), o qual, na condição de adulto, rememora o passado para reconstituir a história de militância política de seu pai e a experiência de violência, fuga e exílio vivenciados por sua família. Sendo assim, a narrativa é constituída a partir da memória da testemunha de segunda geração. Essa questão pode ser evidenciada no seguinte trecho:

- Tererê, arrombaram o jornal! - disse papai (...)

Naquela época ele estava com uns trinta anos. (...)

Eu e o Ricardo - lembro-me como se fosse hoje, embora isso tenha acontecido há tantos anos - jogávamos uma partida decisiva de futebol de botão na mesa grande da sala. Mamãe, grávida, tricotava o enxovalzinho de criança. (PUNTEL, 2006, 13, grifo nosso).

Decerto, devido à idade de Marcos, no momento do acontecimento dos fatos rememorados, percebemos que a reconstituição da história é resultado da experiência da testemunha, mas também do processo de suplementação da memória por terceiros. Neste sentido, a testemunha ficcional, de modo análogo à Marta Nehring, discorre sobre as ameaças e perseguições que motivaram a fuga da família para o exílio, a viagem, a estada e o retorno da família para o Brasil. Neste estudo, destacamos a representação da experiência de estada no exílio, considerando, especialmente, o sentimento de nostalgia, o processo de adaptação, a condição de estrangeiro e a visão utópica de exílio, na ordem em que estas características surgem na narrativa ficcional.

Ricardo e Marcão viajaram com a mãe para o exílio, pois o pai dos meninos já estava em situação de exílio na Bolívia. Marcão pontua a falta de compressão sobre os fatos quando analisa: “(...) embora não tivesse consciência para entender que, a cada barreira policial ultrapassada, íamos perdendo o carimbo de brasileiro na nacionalidade, para receber, em nossos documentos, o

\footnotetext{
${ }^{3} \mathrm{O}$ testemunho do casal pode ser encontrado na obra De muitos caminhos, publicada em 1978 e organizada por Pedro Celso Uchôa Cavalcanti e Jovelino Ramos; ou na obra intitulada Diáspora: os longos caminhos do exílio, publicada pelo casal em 2001.
} 
internacional exilado" (PUNTEL, 2006, p. 33). De acordo com Viñar e Viñar (1992), muitas famílias evitaram falar das causas do exílio, da prisão e da tortura, na falsa esperança de poupar o sofrimento dos filhos. Com a recusa de informações, "retira-se da criança a possibilidade de se situar em sua própria história; bloqueia-se o seu acesso a um conhecimento que permitiria a elaboração de uma situação que ela viveu e que marcou seus pais. (VIÑAR; VINÃR, 1992, p. 72). Neste contexto, a “criança permanece estrangeira ao seu passado e à sua cultura" (VIÑAR; VINÃR, 1992, p. 72). A narrativa ficcional em análise aponta em vários momentos os prejuízos advindos dessa forma de apreender a experiência do exílio. Decerto, a sobrevivência no exílio é regida em torno da compensação das perdas e, por isso, "o exílio jamais se configura como o estado de estar satisfeito, plácido ou seguro" (SAID, 2003, p. 59). No entanto, a compreensão da história impõe a possibilidade de sobreviver a partir de outra perspectiva de vida. De acordo com Said (2003, p. 59), “o exílio é a vida levada fora da ordem habitual. É nômade, descentrada, contrapontística, mas, assim que nos acostumamos a ela, sua força desestabilizadora entra em erupção novamente”.

Após o encontro com o pai, na Bolívia, a família deslocou-se para o Chile, onde fícou até o golpe de 1973. Diante da nova ameaça, Marcão reconheceu a condição de estrangeiros de sua família: "Mamãe estava certa. Os militares chilenos não ficariam telefonando, fazendo ameaças. Éramos estrangeiros - hermanos -, mas hermanos do gobierno que acabava de sucumbir ao golpe militar de Pinochet. Isso era o suficiente para nos complicar.” (PUNTEL, 2006, p. 38). Neste excerto, percebemos a configuração de estrangeiro como aquele que não faz parte do grupo político que ascende ao poder e, por isso, além de ser considerado o "diferente", o "estranho" ou o "intruso", conforme proposto por Kristeva (1994), verificamos que, neste caso, o estrangeiro é também o “inimigo" político. De acordo com Kristeva (1994, p. 101), o "grupo do qual o estrangeiro não faz parte deve ser um grupo social estruturado em torno de um certo tipo de poder político. Inicialmente, o estrangeiro é situado como benéfico ou maléfico para esse grupo social e para o seu poder e, por esta razão, ele deve ser assimilado ou rejeitado.” (KRISTEVA, 1994, p. 101). No contexto de ditaduras civil-militares, os opositores políticos são considerados maléficos para aqueles que estão no poder e, portanto, devem ser perseguidos, excluídos, eliminados. É neste contexto que Marcão considera que a atuação do pai dentro do processo político chileno o tornou "um dos primeiros nomes a encabeçar as listas negras” (PUNTEL, 2006, p. 38) e, por isso, a família deveria esconder-se e fugir, logo que possível.

Após alguns dias de refúgio na embaixada francesa, Marcos e sua família conseguiram partir para França. De acordo com o narrador-testemunha, logo que a família chegou ao país fora assistir ao desfile do 14 Juillet. Isto é, o desfile de 14 de julho, Dia da Independência da França. Na ocasião, 
Marcão afirma que voltou os seus pensamentos às comemorações da Independência no Brasil, ao desfile, à sua namorada Ana Rosa, ao encontro dos dois após o desfile e à lembrança do primeiro e único beijo, com sabor de morango com chantilly. Sobre essas lembranças, o narrador-testemunha afirma: "Ainda mergulhado no 7 de Setembro de Canaviápolis (...) eu levei o maior susto ao levantar a cabeça, me dando conta de que estávamos novamente em Paris" (PUNTEL, 2006, p. 50). Neste trecho, percebemos a saudade da pátria, da cidade onde a personagem vivera a sua infância, do sorvete e da primeira namorada. De acordo com Montañés (2006): “O exílio não é só um estado físico, espacial e temporal, também é um estado mental. O sentimento de perda primordial remete-nos a um sentimento ainda mais profundo que nos acompanha permanentemente no exílio: a nostalgia [...]" (MONTAÑÉS, 2006, p. 29-30). Para Boym (2017), nostalgia “é um sentimento de perda e deslocamento, mas é também uma fascinação com a própria fantasia. O amor nostálgico só pode sobreviver em um relacionamento à distância.” (BOYM, 2017, p. 153). Neste sentido, nostalgia é a evocação a um passado geograficamente demarcado: a terra natal. No entanto, o termo só é passível de definição a partir do momento que este é pensado no presente e, portanto, no local de exílio, pois é resultado de uma nova compreensão do tempo e do espaço. Sendo assim, é a distância que alimenta o sentimento nostálgico e faz com que o exilado viva em constante processo de sobreposição de dois mundos que não se encaixam, porque, em sua essência, são incompatíveis.

Sobre a experiência de exílio na França, Marcão refere-se ao processo de adaptação, especialmente, à língua do país de exílio: "Na França foi muito difícil até conseguirmos entender o que os franceses diziam. Não só o que eles diziam, mas a maneira de eles entenderem o mundo, seus costumes, suas tradições, sua maneira europeia de pensar" (PUNTEL, 2006, p. 52). De acordo com Birol (2017), o idioma pode contribuir ou dificultar o processo de adaptação, dependendo do nível de conhecimento do estrangeiro sobre a língua. Na narrativa ficcional, verificamos que Marcão e seus irmão sentiram algumas dificuldades no início do processo de adaptação à língua; porém, percebemos também que os filhos tiveram mais facilidade no aprendizado da nova língua, em comparação aos pais. Sobre esta questão, é comum os casos em que as crianças se tornaram bilíngues, trilíngues ou, no entanto, perderam totalmente o contato com a língua de origem. José Maria Rabêlo, por exemplo, afirma o seguinte: "Em nossa casa se falam hoje três idiomas. Comigo e a Tereza as crianças conversam em português. Entre si, em espanhol, pois foram alfabetizadas nesta língua e é a que dominam melhor. Com os amigos franceses, em francês" (CAVALCANTI; RAMOS, 1978, p. 172).

De forma geral, a narrativa ficcional também apresenta uma visão utópica do exílio, isto é, de um lugar melhor para se viver. Marcão testemunha sobre a sua alegria, por exemplo, devido à viagem de partida para o Chile: "Mas aquele riso solto, descontraído, era também a certeza de que no Chile 
poderíamos mesmo ter um pouco de paz e tranquilidade" (PUNTEL, 2006, p. 35). Na França, também foi possível perceber a gratidão pela forma em que Marcão e sua família foram acolhidos: "Mas, se voltarmos, seja amanhã, depois, daqui a dois ou três anos, sei lá, nós somos muito gratos a vocês. Gratos pela hospitalidade, pelo carinho e pela amizade" (PUNTEL, 2006, p. 35). Marcão compreendeu o exílio como um lugar melhor para viver, pois se sentiu seguro, respeitado e acolhido. No Brasil, porém, não fora possível viver nessas mesmas condições. Por isso, o personagem testemunha sobre o sofrimento sentido pelo retorno, a insônia misturada com a saudade que já sentia da nova namorada e dos amigos da escola, a preocupação sobre a forma como seriam recebidos no Brasil. No avião, durante a viagem de volta ao Brasil, Marcão relembra o seguinte evento: "Convidado a cantar, recusei. Fechei os olhos, fingindo dormir. Foi a maneira que arrumei para que ninguém percebesse que eu estava chorando" (PUNTEL, 2006, p. 35). Dessa forma, o conto também apresenta o sentimento de tristeza sentido pela testemunha ficcional devido ao retorno ao Brasil, tal como percebemos na experiência testemunhada por Marta Nehring. Verificamos que a tristeza sentida pelo retorno fundamentava-se nas seguintes questões: de um lado, as lembranças negativas do Brasil, a experiência de mais uma viagem, a incerteza sobre a forma como seriam recebidos; de outro lado, a integral adaptação ao local de exílio e o imaginário de que o exílio era uma local melhor para se viver.

\section{Considerações finais}

Neste estudo, verificamos que a presença dos filhos no exílio é um caráter que amplia a violência exercida pelo estado de exceção, aumentando o sofrimento, a insegurança e a angústia, mas também que fortalece o sentido da luta. O testemunho é uma narrativa da sobrevivência ao estado de exceção, pois os filhos dos militantes políticos não vivenciaram a experiência extrema do desaparecimento ou da morte, mas assumiram o compromisso de reconstruir a história de sua família e compreender as lacunas deixadas pelos registros oficiais, em nome da memória de seus pais. Barenghi (2005) afirma que "é graças à vontade de compreender que a recordação se traduz em relato" (BARENGHI, 2005, p. 180). Certamente, devemos salientar que nem sempre as histórias narradas oferecem possibilidades de entendimento, porém: "não se pode renunciar ao objetivo de compreender, porque só o horizonte intelectual da compreensão garante a sobrevivência psíquica do sujeito, preservando-o do abismo da insensatez" (BARENGHI, 2005, p. 182).

O testemunho também é uma forma de resistência, pois a reconstituição da história, a busca pelos corpos dos desaparecidos, o julgamento dos culpados pelos crimes políticos, o desejo de justiça, 
entre outras questões, apresenta-se, atualmente, por meio da memória dos filhos dos perseguidos, desaparecidos e mortos políticos. Neste processo, é importante esclarecer que há experiências nas quais os filhos não tinham noção alguma sobre o contexto histórico da época, a perseguição sofrida pelos pais e, consequentemente, a necessidade de sair do Brasil em busca de refúgio em outro país. Por outro lado, há experiências nas quais os filhos compreendiam, dentro de suas possibilidades, o contexto histórico da época, a situação política de seus pais, a situação de vulnerabilidade e o exílio como uma possibilidade de sobrevivência da família. De qualquer forma, verificamos que as crianças compreenderam o exílio como uma experiência de busca pela liberdade. Nossa hipótese é a de que o discurso utópico emerge da relação existente entre os estudos teóricos do exílio e do testemunho, impulsionado pelo trabalho de reconstituição da história pelos filhos das vítimas diretas da ditadura, ou seja, por meio do trabalho da memória. Assim, a utopia seria o resultado dos contatos existentes entre testemunho, memória, exílio e infância.

Verificamos ainda que: "No fim das contas, o exílio não é uma questão de escolha: nascemos nele, ou ele nos acontece" (SAID, 2003, p.56). Dessa forma, a experiência específica de filhos de militantes políticos corrobora com a percepção de que as crianças são atores involuntários da experiência de exílio, mas que foram, assim como seus pais, diretamente atingidas pelo regime de estado de exceção. A experiência do exílio, para muitos filhos, gerou conflitos não resolvidos até os dias de hoje. Devemos considerar também que as experiências dos filhos são heterogêneas, pois podem ser influenciadas por diversos fatores: o país de exílio, as condições econômicas, materiais, políticas, a idade da criança à época do evento histórico, o nível de envolvimento ou conhecimento das questões políticas, o fato de ter ou não irmãos, o fato de ter viajado para o exílio ou de ter nascido no exílio, entre outras. Este estudo apresentou a análise de narrativas específicas, por isso não foi possível perpassar por essas questões. No entanto, a proposta deste trabalho está além de uma classificação de idade, gênero, nacionalidade ou outra especificidade, mas visa uma abordagem situada no plano do discurso daqueles que vivenciaram a violência imposta pela Ditadura Militar de forma involuntária e precoce.

Sendo assim, a experiência do exílio fora uma condição necessária para sobreviver, em alguns casos, à única possibilidade de preservação da vida. Vimos que a experiência fora caracterizada pela situação de vulnerabilidade das crianças e pelo logro dos direitos fundamentais. Todavia, encontramos a construção de uma visão utópica do exílio. Em linhas gerais, um caminho caracterizado pelo sofrimento, que conduziu a um destino utópico, seria a forma como algumas crianças compreenderam a experiência do exílio e como esta fora representada no campo literário. Em época de violência, a reflexão sobre o autoritarismo é uma atividade necessária, pois pondera sobre a força exercida pelo 
regime ditatorial, mas também sobre as relações de poder existentes, atualmente, na sociedade e a constante busca do ser humano por viver um espaço/tempo de utopia.

\section{Referências}

BARENGHI, Mario. A memória da ofensa. Novos Estudos, São Paulo, n. 73, p. 176-191, 2005.

BASILE, Teresa. Infancias: La narrativa argentina de HIJOS. Villa María: Eduvim, 2019. Libro digital, EPUB (Poliedros).

BIROL, Alline Pedra Jorge. Adaptação (de estrangeiros). In: CAVALCANTI, Leonardo (org.). Dicionário crítico de migrações internacionais. Brasília: Editora Universidade de Brasília, 2017.

BOYM, S. Mal-estar na nostalgia. História da Historiografia: International Journal of Theory and History of Historiography, v. 10, n. 23, p. 153-165. 4 jul. 2017.

CAVAlCANTI, Pedro Celso Uchôa; RAMOS, Jovelino (org.). Memórias do exílio: Brasil (196419??) - 1. De muitos caminhos. São Paulo: Livraria Livramento, 1978.

HIRSCH, Marianne. The generation of postmemory. Poetics Today, Durham, v. 29, n. 1, p. 103-128, 2008.

KRISTEVA, Julia. Estrangeiros para nós mesmos. Rio de Janeiro: Rocco, 1994.

LUQUE, Cecilia Inés. Balún Canán de Rosários Castellanos: un ejemplo de memorias pseudotestimoniales. Contribuciones desde Coatepec, Tocuna, v. 2, n. 4, p. 17-34, 2003.

MARCO, Valéria de. A literatura de testemunho e a violência de Estado. Lua Nova: Revista de Cultura e Política, São Paulo, 2004, n. 62, p. 45-68.

MONTAÑÉS, Amanda Pérez. Vozes do exílio e suas manifestações nas narrativas de Julio Cortázar e Marta Traba. 2006. 203 f. Tese. (Doutorado em Ciências Humanas) - Centro de Filosofia e Ciências Humanas, Universidade Federal de Santa Catarina, Florianópolis, 2006.

NEHRING, Marta. "Por que você é tão tristinha?". In: Comissão da Verdade do Estado de São Paulo. Infância Roubada: crianças atingidas pela Ditadura Militar no Brasil. São Paulo: ALESP, 2014. 
PUNTEL, Luiz. Meninos sem pátria. São Paulo: Editora Ática, 2006.

ROLLEMBERG, Denise. Entre raízes e radares, o exílio brasileiro (1964-1979). In: XI Jornada Interescuelas/Departamentos de Historia. Departamento de Historia. Facultad de Filosofía y Letras. Universidade de Tucumán, San Miguel de Tucumán. 2007. Disponível em: http://cdsa.aacademica.org/000-108/758.pdf. Acesso em: 10 jan. 2018.

SAID, Edward. Reflexões sobre o exílio. In: SAID, Edward. Reflexões sobre o exílio e outros ensaios. São Paulo: Companhia das Letras, 2003.

SARLO, Beatriz. Tempo passado: cultura de memória e guinada subjetiva. Trad. Rosa Freire d'Aguiar. São Paulo: Companhia das Letras; Belo Horizonte: UFMG, 2007.

SELIGMANN-SILVA, Márcio. Narrar o trauma: a questão do testemunho de catástrofes históricas. Psic. Clin., Rio de Janeiro, v. 20, n. 1, p. 65-82, 2008.

SELIGMANN-SILVA, Márcio. "Zeugnis" e "Testimonio": um caso de intraduzibilidade entre conceitos. Letras, n 22: "Literatura e autoritarismo", Rio Grande do Sul, jan.-jun./2001, p.121-130.

SELIGMANN-SILVA, Márcio (org.). História, Memória, Literatura: o testemunho na era das catástrofes. Campinas: Ed. Unicamp, 2003.

SZACHI, Jerzy. As utopias ou a felicidade imaginada. Trad. Rubem César Fernandes. Rio de Janeiro: Paz e Terra, 1972.

VIÑAR, Marcelo; VIÑAR, Maren. Exílio e Tortura. São Paulo: Escuta, 1992. 